\title{
Significance of Technology to Cash Waqf Collection: Application of Unified Theory Acceptance and Use of Technology (UTAUT)
}

Wan Musyirah Wan Ismail

To Link this Article: http://dx.doi.org/10.6007/IJARBSS/v11-i1/8994

DOI:10.6007/IJARBSS/v11-i1/8994

Received: 10 December 2020, Revised: 07 January 2021, Accepted: 19 January 2021

Published Online: 31 January 2021

In-Text Citation: (Ismail, 2021)

To Cite this Article: Ismail, W. M. W. (2021). Significance of Technology to Cash Waqf Collection: Application of Unified Theory Acceptance and Use of Technology (UTAUT). International Journal of Academic Research in Business and Social Sciences, 11(1), 777-788.

\section{Copyright: @ 2021 The Author(s)}

Published by Human Resource Management Academic Research Society (www.hrmars.com)

This article is published under the Creative Commons Attribution (CC BY 4.0) license. Anyone may reproduce, distribute, translate and create derivative works of this article (for both commercial and non-commercial purposes), subject to full attribution to the original publication and authors. The full terms of this license may be seen at: http://creativecommons.org/licences/by/4.0/legalcode

Vol. 11, No. 1, 2021, Pg. 777 - 788

Full Terms \& Conditions of access and use can be found at http://hrmars.com/index.php/pages/detail/publication-ethics 


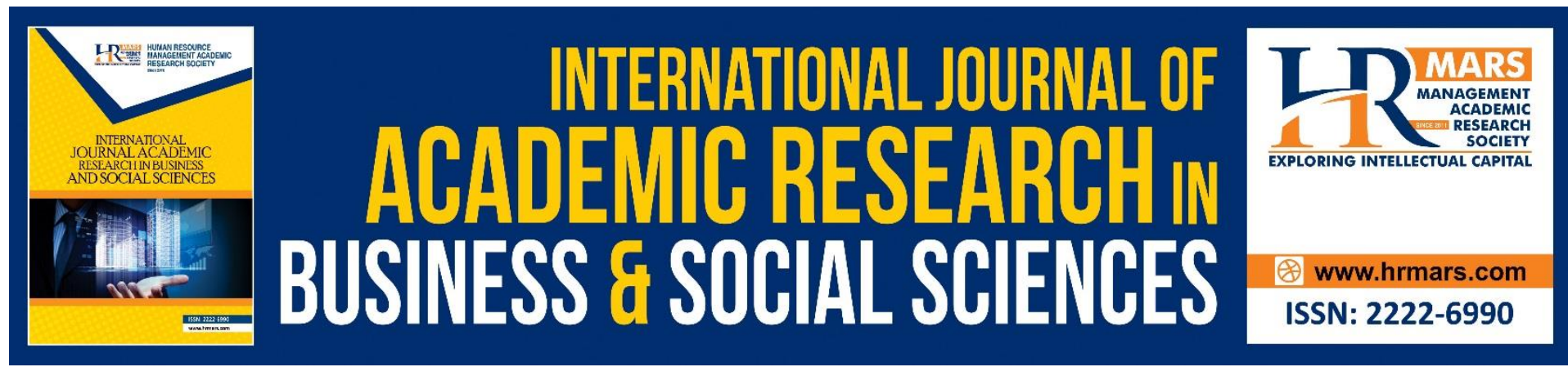

\title{
Significance of Technology to Cash Waqf Collection: Application of Unified Theory Acceptance and Use of Technology (UTAUT)
}

\author{
Wan Musyirah Wan Ismail \\ Universiti Teknologi Mara (UiTM) Cawangan Melaka Malaysia
}

\begin{abstract}
Cash Waqf is an important tool in Islam. Efforts by government agencies and non-government organizations (NGOs) to enhance the role of cash waqf have been increasing. In line with the growing technology, government acknowledged the importance of Information technology (IT), transparency and trust in the implementation of cash waqf. Therefore, this study is aimed to identify the significance of technology towards Cash Waqf collection. Technology acceptance and technology usage are two different terms which each of them might be able to influence the collection of Cash Waqf. It is because, currently collection of Cash Waqf is not at a good level, which concluded only RM0.28 per Muslim for Cash Waqf contribution. Therefore, looking for alternatives that could improve Cash Waqf collection is a good idea. Seeing that we are reached year of 2020 which has been targeted a long time ago with provided good technology, therefore implementation of effective technology nowadays could be one of the ways to encourage contribution of Cash Waqf. Acceptance of technology could lead to high usage of technology. Application of Unified Theory Acceptance and Use of Technology (UTAUT) is relevant to this situation. Thus, it can be concluded that, more people accept technology will encourage more contribution in cash waqf fund. Therefore, more collection in cash waqf fund.
\end{abstract}

Keywords: Cash Waqf, Technology Acceptance, Technology Usage, Collection, Fund.

\section{Introduction}

Cash Waqf plays an important role in Malaysia as it is categorized in government Sustainable Development Goals (SDG) 16 which promote peaceful and inclusive societies for sustainable development, provide access to justice for all and build effective, accountable and inclusive institutions at all levels which would be able to promote peace, justice and develop strong waqf institutions. The management of Cash Waqf from respective institutions considered as an important factor to ensure the collection of Cash waqf achieve the expected amount to fulfil their objectives.

Mohsin (2009) stated, many contemporary scholars believe that contribution of waqf by using cash is much important and more relevant due to its flexibility than waqf properties. According to Ajfan (1985), cash waqf existed and was practiced during the Ottoman period. At the end of the 16th century, the concept of cash waqf was fully acceptable by the entire Antonia and the European provinces of the Ottoman Empire which equally controlled some 
parts of South Eastern Europe, the Middle East and North Africa. During that time, the collection of cash waqf were used to purchase and developed many types of fixed assets such as buildings of schools, libraries, hospitals, water channels, bridges, roads, ports and lighthouses (Mohsin, 2009).

Cash Waqf plays a big role in economy and society in the country, and also play a vital role in the advancement of socio-economic wellbeing of the Muslim community (Ali, 2017). In Malaysia, Cash Waqf is one of the alternative instruments that can overall improve the social welfare and reduce the poverty rate and at the same time, lessen the burden of the government. Most governments today have financial problems and face insufficient funds to meet the public welfare and to ensure that all their citizens are in good standing. The Malaysian government for an instance allocates RM 2.6 billion in its recent Social Safety Net Program called "Bantuan Rakyat 1 Malaysia". Therefore, Cash Waqf can contribute to the development and stability of Malaysia (Marzuki et al, 2012).

In order to improve the collection of Cash Waqf, technology seems to be one of the solutions. Technology is a key channel in the financial sector, and it will be an opportunity for them to increase their efficiency in achieving their objectives. Technology can also provide a better experience and convenience for users (Devadevan, 2013). Isa (2014); Ahmad et. al (2014); Nasiri (2019) study on the acceptance of online Cash Waqf which adoption of technology in the Cash Waqf collection system. Economically, there are payment services, banking industry and financial regulations that apply new technologies. The emergence of new information technology in the financial services industry known as "FinTech". It is the word derived from the combination of "finance" and "technology". For example, mobile banking provides users with the ability to remotely make financial transactions using a mobile device such as a smartphone or tablet and can be provided by a financial services provider. Such services are not limited to mobile payments but include the use of debit or credit cards to influence Electronic Funds Transfer on Point of Sales (FTPOS) payments (Arputharaj, 2016).

\section{Literature Review \\ Technology Acceptance}

Binbasioglu (2020) define technology acceptance as the adaptation of the process and a system that is claimed to be due to different variables by the user of new technology. Topi (2010) insist that technology acceptance is occurs when users intend to use the technology. Information and technology (ICT) is a technology tool used in communication, processing and sending of information in electronic form (Noor, 2006). Nayak et. al, (2010) explain the use of ICT can be in terms of disseminating information, social interaction, education, entertainment, health and so on.

IT started its era around 1990s, and until now it is still developing rapidly. National development in Malaysia was go through various changes from time to time, beginning from the agricultural to the industrial development, then to the transformation in the ICT field. ICT is aid to develop and to ensure the growth of a national economy especially in developing countries (Walsham et, al., 2007). Walsham et, al (2007) is surely right about the development of information technology because, as he may not be aware, recent studies have shown that digital technology which is part of ICT, has been widely used in Malaysia, starting introduced in 1874 by the used of telephone network, followed by the introduction of computer technology in 1966. Usage of ICT being emphasized since the Eight Malaysia Plan, where the government start to take a step to inculcate ICT, which then followed by the Ninth and Tenth plans where ICT used as a key enabler and one of the components and major objectives in 
national development. Hassan et, al (2012) believes that there are many ways taken in order to achieve this mission where various programs and projects were carried out such as Smart Schools, telehealth, research and development cluster, Multimedia Super Corridor, cyber city and so forth.

Halili et, al. (2017) demonstrates that Malaysia targets to be a developed nation by 2020, thus they take the initiative to widen ICT usage in society in order to bridge the digital divide and in efforts to expand the knowledge-based economy. For this reason, the Malaysian government introduced the National Telecommunications Policy in 1994 in order to enhance the capacity to use ICT in society. The national Vision 2020 emphasized society to widely expose on information and knowledge. In efforts to achieve Vision 2020, the Government has carried out several programs and prepared the requisite infrastructure. Rapid development of ICT use could be one of the elements that contribute to the economic and social development in Malaysia. It is supported by Kriz \& Qureshi (2009); Dinc (2016) that ICT is a tool to economic development. In fact, most of the countries all over the world have used various approaches to implement ICT usage in developing society and use the opportunity to widen ICT usage in community development. I totally agree that ICT is developing and government targeted year 2020 to be high usage of technology advancement because my experience grew up in that times confirm it.

In the early year of 2020, world facing covid-19 which affected most of the country with high number of deaths. Due to the situation, most of the countries implement lockdown for a few months because of its unusual fast rate of the virus spreading, the widest scope of infection, and the most difficult to prevent and control in most of country in the world since its establishment in China (Kidman \& Chang, 2020; Kraemer et al., 2020; Zhou et al., 2020)The big impact to the country where everyone needs to accept the technology as world need to lockdown and do most of the things from home. As in China, companies could immediately adapt due to technological capabilities, when the government encouraged millions to remain at home (Siva, 2020).

\section{Technology Usage}

Technology is defined as a body of knowledge used to create tools, processing actions and extracting of materials (Ramey, 2013). According to Cambridge Dictionary, technology is the method of using scientific discoveries for practical purposes especially in computer, teaching, medical and space technology. It is also referred to use of scientific knowledge in the area of business, industry, processing in manufacturing such as processing of food using technology food processor, gene technology, and technology stocks or shares.

In our daily life nowadays, technology is like a common need as we used technology everywhere such as at work, at home and on the road. Technology nowadays used for communication; handphone and tablet, learning; LCD and computer, transportation; car and aeroplane, business; online selling, manufacturing; machine of processing in factory and securing data. Technology process is consisting of tools, materials and systems which end of results is a product. Technology has its own advantages and disadvantages, where if it is used in the right way, it will give much benefit to us, and if it is use in other way, it will have damaged us (Ramey, 2013).

As technology brings many benefits to the users if it is used in the right way, therefore, the implementation of technology in Waqf could be advantageous for the public as well as to the Waqf sector itself. Datuk Seri Dr Mujahid Yusof Rawa, the former minister at the Prime Minister Department mentioned that Malaysia is set to move towards digitalisation and 
financial technology (FinTech) in Waqf sector, where the government are working with experts in the Information Technology (IT) space in order to use artificial intelligence (AI) and blockchain in Waqf sector. The government believe that, IT as well as digital economy, play an important role in highlighting the issue of transparency and trust in the implementation of Waqf. The CEO of Finterra, Hamid Rashid agreed that blockchain technology is a good idea and great solution to create a smart contract linked to specific Waqf ventures in order to create more effective way of raising funds and controlling and transferring ownership of Waqf donations (Noordin, 2018). Both Mujahid and Hamid focused on technology usage in the application of Cash Waqf collection to improve the Cash Waqf system in Malaysia.

Blockchain is a digital or electronic database containing almost any type of information like transactions, resources or identities which could be stored in a digital format. The stored information stored is permanent, transparent and searchable for the authorised person to use it. Such characteristics of blockchain technology are advantageous and useful to the management of Waqf (Adilla, 2019; Noordin, 2018).

Parallel to this usefulness of blockchain technology, Noordin (2018) mentioned that, Hamid Rashid who is CEO of Finterra Pte Ltd; one of the Singapore based financial technology company, was launched endowment chain, that is blockchain solution for waqf in 2018 as an alternative to increase the potential of utilising waqf contribution for the right way. This is suitable to waqf as waqf is one of the Islamic philanthropies, because it is built with smart contracting engine that according to shariah principles. In addition, blockchain technology for waqf is not the same as bitcoins which allows anonymity, but blockchain for waqf restricted to every transaction would require compliance with know your customer and anti-money laundering regulations. It is incorruptible and unalterable. The copies of the ledger are distributed to the community, it is called as nodes. It requires the public ledger to follows a " $51 \%$ rule", which if it is more than $51 \%$ of the nodes do not agree with the changes, then they cannot be made, thus it will be deleted. This contribute to no point of failure, it is because, hackers who wants to manipulate the blockchain, would need to attack all the nodes at once (Noordin, 2018).

\section{Unified Theory of Acceptance and Use of Technology (UTAUT)}

In order to know how usage of technology will influence intention to contribute in cash waqf, researcher use Unified Theory of Acceptance and Use of Technology (UTAUT) model in order to investigate the relation of a few factors to influence intention of use of technology. UTAUT is a model proposed by Ventakesh et. al (2003) is a theory of technology acceptance model that describes how factors like performance expectancy, effort expectancy, social influence and facilitating conditions will influence behavioural intentions of using technology (Raman et. al, 2014). 


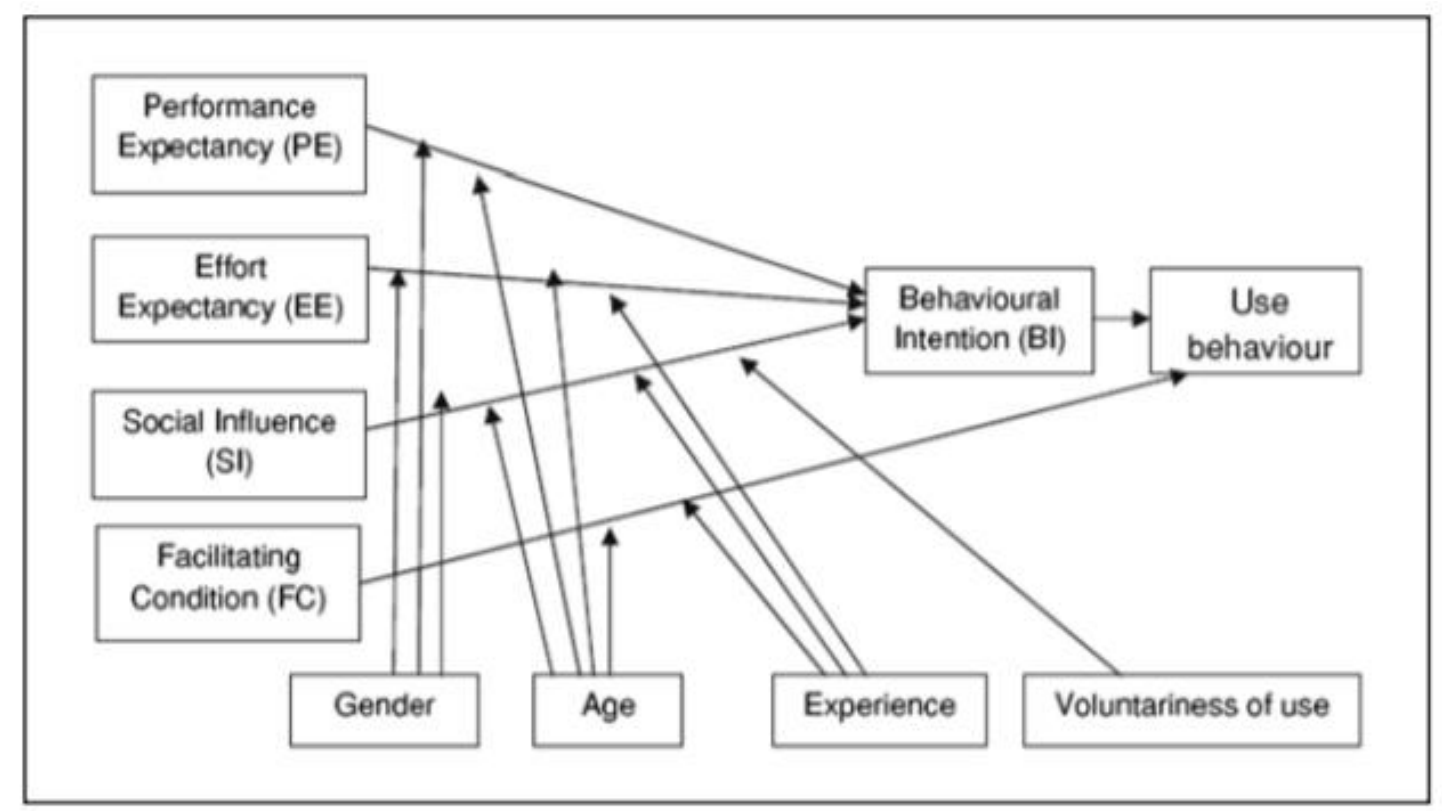

Figure 1

Unified Theory of Acceptance and Use of Technology (UTAUT) by Ventakesh et. al, 2003

According to Ventakesh et. al (2003) Performance expectancy is where people use technology since they believe that it will improve their work performance. Effort expectancy is referred to the level of ease that beneficial to the user when they used the system or technology. Social influence is where people perceived that their superior believes that they should use the system or technology. Facilitating conditions is refer to how far individual thinks that their organization or company provide technical infrastructure in order to support the system or new technology. Beside these four factors, there are other four factors that may affect the usage of technology.

\section{Cash Waqf Collection}

\begin{tabular}{|c|c|}
\hline Year & $\begin{array}{c}\text { Total Collection of } \\
\text { Cash Waqf (RM) }\end{array}$ \\
\hline 2019 & $2,850,942.82$ \\
\hline 2018 & $2,781,107.54$ \\
\hline 2017 & $2,667,079.56$ \\
\hline 2016 & $2,184,805.45$ \\
\hline 2015 & $2,034,494.72$ \\
\hline 2014 & $2,063,153.72$ \\
\hline 2013 & $988,651.74$ \\
\hline 2012 & $445,078.52$ \\
\hline 2011 & $396,318.17$ \\
\hline 2010 & $399,923.80$ \\
\hline
\end{tabular}

Table 1

Source: Yayasan Waqf Malaysia

\begin{tabular}{|c|c|}
\hline Year & $\begin{array}{c}\text { Total Population of } \\
\text { Muslims in Malaysia }\end{array}$ \\
\hline 2019 & $21,293,496$ \\
\hline 2018 & $21,193,067$ \\
\hline 2017 & $21,092,637$ \\
\hline 2016 & $20,992,208$ \\
\hline 2015 & $20,891,779$ \\
\hline 2014 & $20,791,349$ \\
\hline 2013 & $20,690,920$ \\
\hline 2012 & $20,590,491$ \\
\hline 2011 & $20,490,061$ \\
\hline 2010 & $20,389,632$ \\
\hline
\end{tabular}

Table 2

Source: worldometers, 2019 \& The Future of World Religious, 2019 (Forecasting)

Table 1 shows the total amount collection of Cash Waqf (Yayasan Waqf Malaysia, 2020) and Table 2 is the total of Muslim's population in Malaysia (wordometers, 2019). 
According to Labour Force Statistics Malaysia, (2019), percentage of labour force in Malaysia is $68.9 \%$ from total population in Malaysia, while employed is $69.5 \%$ from labour force. Based on Table 3 above, number of Muslim in 2019 is 21,293,496 people. Thus, number of Muslim's labour force in Malaysia in 2019 is 14,671,218.74 and from that, employed Muslim in 2019 is 10,190,291.90 people. The total amount of Cash Waqf in 2019 is RM 2,850,942.82, thus resulted to the contribution of RM 0.28 for the amount of cash waqf per Muslim.

Even though Cash Waqf is still not at the high achievement yet, but it is forecasted that it will has a potential to develop in the future. The researcher believes that Cash Waqf will be well developed in the future, a point that need emphasizing since so many people believe the development of Cash Waqf. It is supported with the research done by AnwarAllah et al., (2014), Cash Waqf has the potential to develop and able to promote the development of Ummah. He estimated that the collection of Cash Waqf in Malaysia could reach RM 4.3 billion a year.

\section{Significance of Technology towards Cash Waqf Collection}

Acceptance of technology towards Cash Waqf could be reality when realizing that acceptance of internet and social media nowadays is very good. Refer to Adeyami et, al. (2016) agree that currently, the use of social media method such as Facebook, Youtube, Instagram, Mobile Application in making public aware was quite effective. Therefore, it shows that high acceptance of technology nowadays could be implement in Cash Waqf collection method.

I agree that the use of technology in Cash Waqf seems to be important as it could be more efficient and effective way to collect Cash Waqf. It was mentioned by Adeyami et, al. (2016) who agree that by using online payment method, it will make it easier for people to give their contribution or donation without any hassle. The responsibility to encourage Cash Waqf contribution should not only bear by the Waqf institutions, but it could be more successful if there is collaboration and coordination from others such as people in society, including individuals, any institutions like non-profit organizations, civil society as well as government.

The researcher agrees with Puad et al., 2014 as she suggest institution of waqf such as MAIS to integrate with telecommunication companies in Malaysia like Telekom to establish an easy and convenient way for society. She proposes MAIS to develop electronic system such as SMS to make easy for the public to perform Waqf, collaborate with banks to offer Cash Waqf deposit through ATM machines. As my observations, there are cash waqf contribution through banking system nowadays. However, it is limited to only one place per banking system. My own view, however is that, parallel to technologies advancement nowadays, where people tend to use technology more than traditional way such as online system, I suggest to pool many sources of Cash Waqf collector in one place either in banking system, kiosk, application or SMS with all collector need to be registered to the responsible institution of Cash Waqf to build trust from the public and convenience for them to easily choose which they preferred to contribute.

\section{Conceptual Framework}

The waqf institution is a non-profit organization, therefore, the use of advanced technologies such as servers, programs and software are at a minimal level compared to profit making organizations such as financial institutions. However, based on the current situation and in order to accumulate a greater amount of cash waqf fund collection, Waqf institutions 
should also use the same or at least equivalent technology as financial institutions because Waqf institutions are also related to money (Khamis \& Salleh, 2018). Iman et, al. (2014) state that the SIRC does not have a comprehensive and reliable information system, which is reliable to assist in development planning. This leads to errors, incomplete data, inconsistencies, duplicates and missing or records.

Waqf institutions are encouraged to use their own financial resources as they rely on limited federal funds, therefore, it appears that the majority of Waqf institutions have initiated collecting Waqf funds in various ways and mediums, which help them to be more confident in maintaining the future. It is believed that these institutions have their own uniqueness and ability to promote the concept of Waqf to the community. This is important because, if they depend on the limited financial resources of the federal government, it will be a weakness for Waqf management (Siraj et, al., 2012). As such, when these Waqf institutions have the ability to innovate new ways of promoting cash waqf and proactively implementing current technologies such as e-wakaf, bank draft and online Waqf, this will attract the private sector to participate in Waqf recovery.

Sargeant \& Woodlife (2005) found that payment methods are the attraction for the donors to retain their contribution. Jalil et, al (2017) stated that there is still no study found that covering payment methods and Cash Waqf in Malaysia. Technology adoption involve various method of payment such as mobile banking and mobile payment shows increasing number of usages through the end of year 2010 (Jalil et, al., 2017). According to Mohsin et, al. (2019), he believed that waqfintech could reach a wider audience and benefit more people in need using innovative financial technology like crowdfunding and blockchain. Anwar et, al. (2018) mentioned that existing models of cash waqf are criticized as ineffective in attracting more donors and donors are often unaware of how their contributions are utilized. Additionally, mismanagement and lack of transparency in waqf fund management all contribute to inefficiencies in waqf administration (Thaker et, al., 2018; Mohsin\&Muneeza, 2019; Mohsin et al., 2016). Therefore, innovative finance technology such as crowdfunding platforms and blockchain expected to improve the management of Cash Waqf as well as able to increase the collection of Cash Waqf.

Amin et al., (2014) stated that acceptance of online waqf contribution among the public is still at infancy level. It was support by Ahmad et al. (2014) and Ahmad \& Muhamed (2011) who found that age of people influences the acceptance of technology used for waqf collection. It means that not all ages are accepted to use technology for waqf purpose. Shukor et al., (2017) mentioned that, convenience in contributing in Cash Waqf is vital in order to encourage contribution of Cash Waqf. It can be achieved by provide greater access to online facilities which it can reach young, increasingly IT literate, generation to promote online Waqf. It shows that young generation is the target for acceptance of technology used in Cash Waqf system. Therefore, age factor might be issue of acceptance of technology, thus the research needs to be conduct in order to encourage all ages to use technology for the purpose of easier way to contribute in Cash Waqf.

Based on this situation, this study would like to identify the significance of technology in Cash Waqf collection.

\section{Conclusion}

Technology acceptance influence the contribution of Cash waqf since people who accept technology tend to use facilities offered with useful technology implementation to 
contribute to cash waqf. More people accept technology will encourage more contribution in cash waqf fund. Therefore, more collection in cash waqf fund.

On the other hand, technology usage influence contribution to cash waqf because people who prefer to use technology facilities would be easier to give fund to cash waqf. It is because, technology offered would let them do everything just at fingertip. It is to ensure people enjoy the facilities provided with no hassle and easily tend to contribute to cash waqf. Thus, more efficient the technology, easier for Muslim to enjoy the usage. It will influence the collection of cash waqf in Malaysia.

\section{Acknowledgement}

Thanks to my beloved family for endless support during my study, to my supervisors and my colleagues for always give valuable feedback and response. Thanks to the researcher who published their paper as my guidance in this paper.

\section{References}

Adeyemi, A. A., Ismail, N. A., \& Hassan, S. S. B. (2016). An empirical investigation of the determinants of cash Waqf awareness in Malaysia. Intellectual Discourse, 24, 501-520.

Adilla, F. (2019). Local waqf sets to move into digitalisation. News Straits Times. https://www.nst.com.my/business/2019/07/503817/local-waqf-sets-movedigitalisation.

Ahmad, M., Isa, M., Palil, R., \& Dolah, N. H. (2014). Online Waqf Acceptance and Determinant Factors. International Journal of Business, Economics and Law, Vol. 5, Issue 2 (Dec.) ISSN 2289-1552, 5(2), 28-35.

Ahmad, S., \& Muhamed, N. D. (2011). Institusi Wakaf dan Pembangunan Ekonomi Negara: Kes Pembangunan Tanah Wakaf di Malaysia Wakaf Institutions and National Economic Development : A Case on Wakaf Land Development in Malaysia. Prosiding PERKEM VI, 1, 138-147.

Ali, M. M. (2017). Unleashing the Potential of SCM. News Straits Times. https://doi.org/10.4018/jeis.2005010103

Amin, H., Rahman, A. R., Ramayah, T., Supinah, R., \& Aris, M. (2014). Determinants of online waqf acceptance: An empirical investigation. Electronic Journal of Information Systems in Developing Countries, 60(1), 1-18. https://doi.org/10.1002/j.16814835.2014.tb00429.x

AnwarAllah, P., Kameel, M. M., \& Yusuf, S. (2014). Priority of Waqf Development among Malaysian Cash Waqf Donors: An AHP Approach. Journal of Islamic Finance, 3(1), 1322.

https://ikr.inceif.org/bitstream/INCEIF/1374/1/priority_waqf_development_malaysia n_cash_waqf_donors_AHP_approach_yusuf_saleem.pdf

Arputharaj, S. (2016). Advantages and disadvantages of mobile banking in India. National Conference on Emerging Business Strategies in Economic Development (pp. 73-77).

Binbasioglu, H., \& Turk, M. (2020). Mobile Technology Acceptance Among Turkish Travelers. In Digital Marketing Strategies for Tourism, Hospitality, and Airline Industries (pp. 111140). IGI Global. https://doi.org/10.4018/978-1-5225-9783-4.ch006

Department of Statistics Malaysia. (2017).

https://www.dosm.gov.my/v1/index.php?r=column/ctwoByCat\&parent_id=115\&men u_id=LOpheU43NWJwRWVSZkIWdzQ4TIhUUT09 
Devadevan, V. (2013). Mobile Banking in India - Issues \& Challenges. International Journal of Emerging Technology and Advanced Engineering, 3(6), 516-520. http://citeseerx.ist.psu.edu/viewdoc/download?doi=10.1.1.413.6951\&rep=rep1\&type $=$ pdf

Dinc, M. (2016). Introduction to Regional Economic Development. In Introduction to Regional Economic Development (Issue December 2015). https://doi.org/10.4337/9781785361357

Halili, S. H., Sulaiman, H., \& Razak, R. A. (2017). Information and communications technology acceptance among Malaysian adolescents in urban poverty. Turkish Online Journal of Educational Technology, 16(1), 47-54.

Hassan, M. A., Samah, B. A., Shaffril, H. M., \& D'Silva, J. L. (2011). Perceived usefulness of ICT usage among JKKK members in Peninsular Malaysia. Asian Social Science, 7(10), 255266. https://doi.org/10.5539/ass.v7n10p255

Iman, A. H. (2014). Waqf Property: Concept, Management, Development, and Financing. UTM Press.

Isa, M. (2014). The Acceptance of Online Waqf in Islamic Banking Institutions Master in Islamic Finance and Banking [Universiti Utara Malaysia]. http://etd.uum.edu.my/4685/2/s812880_abstract.pdf

Jalil, M. I. A., Pitchay, A. A., \& Yahya, S. (2017). Cash Waqf and Preferred Method of Payment: Case of Malaysia Using an AHP Approach. Revitalization of Waqf for Socio-Economic Development, 2(January 2019), 187-206. https://doi.org/10.1007/978-3-030-184490_10

Khamis, S. R., \& Salleh, M. (2018). Study on the Efficiency of Cash Waqf Management in Malaysia. Journal of Islamic Monetary Economics and Finance, 4(1), 61-84. https://doi.org/10.21098/jimf.v4i1.732

Kidman, G., \& Chang, C. H. (2020). What does "crisis" education look like? International Research in Geographical and Environmental Education, 29(2), 107-111. https://doi.org/10.1080/10382046.2020.1730095

Kraemer, M. U. ., Yang, C.-H., Gutierrez, B., Wu, C.-H., \& Klein, B. (2020). The Effect of Human Mobility and Control Measure on the COVID-19 Epidemic in China. Science, 4218(March).

Kriz, K., \& Qureshi, S. U. E. (2009). The Role of Policy in the Relationship between ICT Adoption and Economic Development: A Comparative Analysis of Singapore and Malaysia. GlobDev 2009, 1-31. http://aisel.aisnet.org/globdev2009/13

Marzuki, M. U., Shahimi, S., Ismail, A. G., \& Embong, Z. (2012). Tackling Poverty : A Look At Cash Waqf. Prosiding Perkem Vii, 2, 1611-1623.

Mohsin, M. I. (2009). Cash Waqf: A New Financial Product. Prentice Hall.

Mohsin, M. I., Dafterdar, H., Cizakca, M., Alhabshi, S. O., Sadr, S. K., Anwar, T., \& Obaidullah, M. (2016). Palgrave Studies in Islamic Banking, Finance, and Economics (Z. Iqbal, J. Sultan, \& M. Asutay (eds.)). Palgrave Macmillan.

Mohsin, M. I., \& Muneeza, A. (2019). Integrating Waqf Crowdfunding into the Blockchain. In U. A. Oseni \& S. N. Ali (Eds.), Fintech in Islamic Finance Theory and Practice (pp. 266280).

Mokthar, M. Z. (2018). Penang Muslims' Perception on Factors Influencing Intention to Give Cash Waqf. International Journal of Academic Research in Business and Social Sciences, 8(5), 864-874. https://doi.org/10.6007/ijarbss/v8-i5/4225 
Nasiri, A., Noori, A., \& Salleh, M. C. M. (2019). Acceptance and Practices of Cash WAQF among University's Students. International Journal of Academic Research in Accounting, Finance and Management Sciences, 9(3), 38-48. https://doi.org/10.6007/ijarafms/v9i3/6325

Nayak, S. K., Thorat, S. B., \& Kalyankar, N. V. (2010). Reaching the Unreached: A Role of ICT in Sustainable Rural Development. International Journal of Computer Science and Information Security, 7(1), 220-224. http://arxiv.org/abs/1002.2134

Noor, S. (2006). ICT Management Centre for Rural Community in Peninsular Malaysia, pp: 2126. Inaugural Lecture Series, Technology University of Malaysia. Skudai, Johor: UTM Press.

Noordin, K. A. (2018). Islamic Finance: Using blockchain to solve wakaf challenges. The Edge Malaysia. https://www.theedgemarkets.com/article/islamic-finance-using-blockchainsolve-wakaf-challenges

Pitchay, A., Thaker, M. A., Mydin, A. A., Azhar, Z., \& Latiff, A. R. (2018). Cooperative-waqf model: a proposal to develop idle waqf lands in Malaysia. ISRA International Journal of Islamic Finance, 10(2), 225-236. https://doi.org/10.1108/IJIF-07-2017-0012

Puad, N. A. M., Rafdi, N., \& Shah, S. W. S. (2014). Issues and Challenges of Waqf Instrument: A Case Study in MAIS. E-Proceedings of the Conference on Management and Muamalah, May 2014, 116-127. https://doi.org/10.1007/s13398-014-0173-7.2

Raman, A., Don, Y., Khalid, R., \& Rizuan, M. (2014). Usage of learning management system (Moodle) among postgraduate students: UTAUT model. Asian Social Science, 10(14), 186-192. https://doi.org/10.5539/ass.v10n14p186

Ramey, K. (2013). What Is Technology -Meaning Of Technology And Its Use. Use of Technology. https://www.useoftechnology.com/what-is-technology/

Salleh, D. D. (2009).Jangan Jadi Penghalang Membangun Tanah Wakaf. (M. Gunawan, Interviewer)

Sargeant, A., \& Woodliffe, L. (2005). The antecedents of donor commitment to voluntary organizations. Nonprofit Management and Leadership, 16(1), 61-78. https://doi.org/10.1002/nml.90

Shukor, S. A., Anwar, I. F., Aziz, S. A., \& Sabri, H. (2017). Muslim attitude towards participation in cash WAQF: Antecedents and consequences. International Journal of Business and Society, 18(S1), 193-204.

Siraj, S. A. (2012). An Empirical Investigation Into The Accounting, Accountability And Effectiveness Of Waqf Management In The State Islamic Religious Councils (Sircs) In Malaysia [Cardiff University]. https://doi.org/10.11113/sh.v8n1-2.840

Thaker, M., T. (2018). Factors Influencing the Adoption of the Crowdfunding- Waqf Model (CWM) in the Waqf Land Development. Journal of Islamic Marketing, 9(3), 1-39.

Topi, H., Tucker, A. (2013). Computing Handbook; Information System and Information Technology. 2013.

Venkatesh, V., Morris, M. G., Davis, G. B., \& Davis, F. D. (2003). User acceptance of information technology: Toward a unified view. MIS Quarterly: Management Information Systems, 27(3), 425-478. https://doi.org/10.2307/30036540

Walsham, G., \& Robey, D. (2007). Special Issue on Information Systems in Developing Countries. Special Issue on IS in Developing Countries, 31(2), 317-326.

Wordometer. (2019). Malaysia Population. https://www.worldometers.info/worldpopulation/malaysia-population/ 
Zhou, L., Wu, S., Zhou, M., \& Li, F. (2020). 'School's Out, But Class' On', The Largest Online Education in the World Today: Taking China's Practical Exploration During The COVID19 Epidemic Prevention and Control As an Example. SSRN Electronic Journal, 4(2), 501509. https://doi.org/10.2139/ssrn.3555520 